\title{
Recent Possibilities for the Diagnosis of Early Pregnancy and Embryonic Mortality in Dairy Cows
}

\author{
Ottó Szenci
}

check for updates

Citation: Szenci, O. Recent Possibilities for the Diagnosis of Early Pregnancy and Embryonic Mortality in Dairy Cows. Animals 2021, 11, 1666 https://doi.org/10.3390/ani11061666

Academic Editors: João Simões and Fiammetta Berlinguer

Received: 31 March 2021

Accepted: 27 May 2021

Published: 3 June 2021

Publisher's Note: MDPI stays neutral with regard to jurisdictional claims in published maps and institutional affiliations.

Copyright: (C) 2021 by the author. Licensee MDPI, Basel, Switzerland. This article is an open access article distributed under the terms and conditions of the Creative Commons Attribution (CC BY) license (https:/ / creativecommons.org/licenses/by/ $4.0 /)$.
Department of Obstetrics and Food Animal Medicine Clinic, University of Veterinary Medicine Budapest, H-2225 Üllő-Dóra Major, Hungary; szenci.otto@univet.hu

Simple Summary: Pregnancy diagnosis plays an essential role in decreasing days open in dairy farms; therefore, it is very important to select an accurate method for diagnosing early pregnancy. Besides traditional pregnancy diagnoses made by rectal palpation of the uterus from 40 to 60 days after AI and measuring the serum or milk progesterone concentration between 18 to 24 days after AI, there are several new possibilities to diagnose early pregnancy in dairy farms. However, it is very important to emphasize that before introducing any new diagnostic test, we need to make sure the accuracy of that particular test to be able to decrease the rate of iatrogenic pregnancy losses caused by prostaglandin or resynchronization treatments. This review focuses on the diagnostic possibilities and limitations of early pregnancy diagnosis in the field.

Abstract: One of the most recent techniques for the on-farm diagnosis of early pregnancy (EP) in cattle is B-mode ultrasonography. Under field conditions, acceptable results may be achieved with ultrasonography from Days 25 to 30 post-AI. The reliability of the test greatly depends on the frequency of the transducer used, the skill of the examiner, the criterion used for a positive pregnancy diagnosis (PD), and the position of the uterus in the pelvic inlet. Non-pregnant animals can be selected accurately by evaluating blood flow in the corpus luteum around Day 20 after AI, meaning we can substantially improve the reproductive efficiency of our herd. Pregnancy protein assays (PSPB, PAG-1, and PSP60 RIA, commercial ELISA or rapid visual ELISA tests) may provide an alternative method to ultrasonography for determining early pregnancy or late embryonic/early fetal mortality (LEM/EFM) in dairy cows. Although the early pregnancy factor is the earliest specific indicator of fertilization, at present, its detection is entirely dependent on the use of the rosette inhibition test; therefore, its use in the field needs further developments. Recently found biomarkers like interferontau stimulated genes or microRNAs may help us diagnose early pregnancy in dairy cows; however, these tests need further developments before their general use in the farms becomes possible.

Keywords: dairy cow; ultrasonography; pregnancy proteins; embryonic mortality; fetal mortality

\section{Introduction}

The extent of pregnancy loss (PL) in dairy cows can be estimated from the difference between the fertilization rate (FR) and the subsequent calving rate (CR). It is generally accepted that the FR in healthy dairy cattle is between $85 \%$ and $90 \%$ [1] or, more recently, around 80\% [2]. The CR has decreased from 66\% since 1951, to about 50\% until 1975 [3], and furthermore to about 33.1\% in Spain [4], 33.4\% in Israel [5], 37\% in Canada [6], 41\% in Japan [7], and $40 \%$ to $44 \%$ in the USA [3,8], while it did not change $(>60 \%)$ in heifers $[9,10]$. Therefore, $41 \%$ to $57 \%$ of pregnancies can be lost during gestation. Most of the losses (early embryonic mortality: EEM) may occur before the maternal recognition of gestation (<Day 16) when the life of the corpus luteum is not extended, and cows return to estrus $[1,11]$. After the maternal recognition of pregnancy, the life of the corpus luteum will be extended, and embryonic mortality (further 5\% to 10\%) occurring between Days 16 and 42 after AI is called late embryonic mortality (LEM), while occurring between Days 42 
to 90 after AI is named early fetal mortality (EFM). Late fetal mortality between Day 90 and term is rare [12]. It has recently been reported that PL after the first month of gestation may range between $3.2 \%$ and $42.7 \%$ [13].

Recently, Pohler et al. [14] have suggested using the terms 'early embryonic development' until Day 30 and 'late embryonic development' between Days 31 and 45 of gestation. Due to the fact that different technical terms are used for this period, perhaps it would be easier to divide the former late embryonic period between Days 16 to 42 into two stages, namely, stage 1 between Days 16 and 30 and stage 2 between Days 31 and 42/45 of gestation.

The PL represents a considerable biological and economic waste for the farmer, therefore, the objective of the present review is to discuss recent methods suitable for diagnosing early pregnancy and pregnancy losses in dairy cattle.

\section{Early Pregnancy Diagnosis (PD)}

\subsection{Real-Time B-Mode Ultrasonography}

During ultrasonographic examination (UE), a cow was initially considered to be pregnant when an irregularly shaped, non-echogenic black spot (or spots) were recognized within the uterine lumen, representing the chorioallantoic fluid [15]. The demonstration of an embryo (later with a beating heart) and/or embryonic membranes provided additional confirmation of pregnancy [16,17]. A normal amount of chorioallantoic fluid in the uterine horn ipsilateral to the ovary with a corpus luteum provided additional confirmation of a normal gestation $[17,18]$. Where no such signs (Table 1) were found, the possibility of pregnancy was ruled out, giving a non-pregnancy diagnosis. The confirmation of ultrasonographic diagnoses was usually based on palpation per rectum of the uterus at 2 to 3 months post-AI, or upon spontaneous return to estrus after AI. A cow was also considered pregnant if an embryo proper with a beating heart was recognized at a final UE on Days 50 to 60 post-AI. Cows diagnosed as non-pregnant by palpation per rectum or by ultrasonography between Days 50 and 90 were usually designated as non-pregnant [19-21].

Table 1. Identifiable characteristics of the bovine conceptus during ultrasonographic examinations for pregnancy diagnosis, indicating the first day of detection.

\begin{tabular}{cccc}
\hline Characteristics & $\begin{array}{c}\text { First day of Detection } \\
\text { in Heifers } \\
\text { Curran et al. [21] } \\
\text { Range }\end{array}$ & $\begin{array}{c}\text { First Day of Detection } \\
\text { in Heifers } \\
\text { Curran et al. [21] } \\
\text { Mean } \pm \text { SEM }\end{array}$ & $\begin{array}{c}\text { First Day of Detection } \\
\text { after ET } \\
\text { Totey et al. [22] } \\
\text { Mean } \pm \text { SD }\end{array}$ \\
\hline Embryo proper & 19 to 24 & $20.3 \pm 0.3$ & $19.5 \pm 0.7$ \\
Heartbeat & 19 to 24 & $20.9 \pm 0.3$ & $22.6 \pm 0.9$ \\
Allantois & 22 to 25 & $23.2 \pm 0.3$ & $23.1 \pm 0.8$ \\
Spinal cord & 26 to 33 & $29.1 \pm 0.5$ & $33.0 \pm 1.5$ \\
Forelimb buds & 28 to 31 & $29.1 \pm 0.3$ & $32.7 \pm 1.3 *$ \\
Amnion & 28 to 33 & $29.5 \pm 0.5$ & $25.1 \pm 1.4$ \\
Hindlimb buds & 30 to 33 & $31.2 \pm 0.3$ & $32.9 \pm 1.3 *$ \\
Placentomes & 33 to 38 & $35.2 \pm 1.0$ & - \\
Split hooves & 42 to 49 & $44.6 \pm 0.7$ & - \\
Fetal movement & 42 to 50 & $44.8 \pm 0.8$ & $50.7 \pm 1.0$ \\
Ribs & 51 to 55 & $52.3 \pm 0.5$ & $60.9 \pm 1.7$ \\
\hline
\end{tabular}

ET: embryo transfer, ${ }^{*}$ forelimb, ${ }^{* *}$ limb buds.

Under experimental conditions, embryonic vesicles in dairy cows can be detected as early as at 9 [23], 10 [20], or 12 days [24] of gestation; however, an accurate pregnancy diagnosis (100\%) can be reached only on Days 20 and 22 of gestation [25], when the embryo (20.3 days) and its heartbeat (20.9 days) can be detected [21]. It is important to mention that fluid accumulation in the chorioallantois during early pregnancy can be easily confused with the uterine fluid within the uterus during pro-estrus and estrus [25]. 
Under on-farm conditions, between Days 22 to 49 after AI, the sensitivity, specificity, positive predictive value, and negative predictive value of ultrasonographic diagnoses made with a $5 \mathrm{MHz}$ linear-array or sector transducer varied between $95 \%$ and $100 \%, 67 \%$ and $100 \%, 85.7 \%$ and $100 \%$, and $84 \%$ and $100 \%$, respectively (Table 2 ).

Table 2. Accuracy of ultrasonographic examinations for diagnosing early pregnancy in dairy cattle by using a $5.0 \mathrm{MHz}$ linear-array or sector transducer.

\begin{tabular}{|c|c|c|c|c|c|c|}
\hline $\begin{array}{c}\text { Days } \\
\text { after AI }\end{array}$ & $\mathbf{N}$ & $\begin{array}{c}\text { Sensitivity } \\
(\%)\end{array}$ & $\underset{(\%)}{\text { Specificity }}$ & $\begin{array}{c}\text { Positive } \\
\text { Predictive Value } \\
(\%)\end{array}$ & $\begin{array}{c}\text { Negative } \\
\text { Predictive value } \\
(\%)\end{array}$ & References \\
\hline $22-40$ & 435 & 96.2 & 71.1 & 89.6 & 87.8 & Filteau and DesCoteaux, [26] \\
\hline $25-29$ & 101 & 98 & 91.3 & 93 & 97.6 & \multirow{2}{*}{ Szenci et al. [27] ${ }^{\mathrm{a}}$} \\
\hline $30-39$ & 143 & 100 & 100 & 100 & 100 & \\
\hline $26^{b}$ & 48 & 100 & 96.7 & 94.4 & 100 & \multirow{2}{*}{ Romano et al. [17] } \\
\hline $27^{b}$ & 53 & 100 & 92.8 & 92.6 & 100 & \\
\hline $26-33$ & 85 & 97.7 & 87.8 & 89.6 & 97.2 & Pieterse et al. [15] \\
\hline $29^{c}$ & 151 & 100 & 96.3 & 91.3 & 100 & \multirow{2}{*}{ Romano et al. [17] } \\
\hline $30^{c}$ & 151 & 100 & 97.4 & 91.9 & 100 & \\
\hline $30-39$ & 722 & 95 & 67 & 89 & 84 & \multirow{2}{*}{ Hanzen and Laurent [28] } \\
\hline $40-49$ & 620 & 98 & 77 & 92 & 94 & \\
\hline $31-35$ & \multirow{2}{*}{323} & 98 & 80 & 85.7 & 97 & \multirow{2}{*}{ Munoz del Real et al. [29] } \\
\hline $36-40$ & & 97 & 93 & 93.6 & 97 & \\
\hline
\end{tabular}

${ }^{\mathrm{a}}$ Sector transducer, ${ }^{\mathrm{b}}$ Heifers, ${ }^{\mathrm{c}}$ Cows, NG: not given. Sensitivity $=$ correct positive $/$ correct positive + false negative $\times 100$. Specificity $=$ correct negative/correct negative + false positive $\times 100$. Positive predictive value $=$ correct positive $/$ correct positive + false positive $\times 100$. Negative predictive value $=$ correct negative $/$ correct negative + false negative $\times 100$.

In contrast, Badtram et al. [30] reported that the sensitivity and specificity of the ultrasound test between Days 23 and 31 post-AI were only $68.8 \%$ and $71.7 \%$, respectively. In a recent study, maximum sensitivity and negative predictive value were reached at Day 26 in dairy heifers and at Day 29 in dairy cows, while the specificity and positive predictive values were $96.7 \%$ and $94.4 \%$ for dairy heifers and $96.3 \%$ and $91.3 \%$ for dairy cows, respectively [17]. In contrast, according to Nation et al. [16], due to pregnancy loss, Days 28 to 35 after AI are too early for reliable detection of pregnancy in dairy cows.

Between Days 27 to 34 after AI, the sensitivity, specificity, positive predictive value, and negative predictive value of ultrasonographic diagnoses made by the use of $5-10 \mathrm{MHz}$ transducer varied between $90 \%$ and $96.6 \%, 91.5 \%$ and $100 \%, 88.4 \%$ and $100 \%$, and $92.3 \%$ and $97.8 \%$, respectively (Table 3 ). When the recognition of an embryo proper with a beating heart was used as the criterion for a positive ultrasound PD, significantly $(p<0.001)$ more false negative and less false positive ultrasound diagnoses were made, in comparison with the recognition of chorioallantoic fluid [31]. In contrast, Silva et al. [18] reported that the presence of chorioallantoic fluid in the uterine lumen and a corpus luteum alone might lead to more false positive results than when an embryo was visualized by using a $5-10 \mathrm{MHz}$ linear-array transducer on Day 27 after timed AI. 
Table 3. Accuracy of ultrasonographic examinations for diagnosing early pregnancy in dairy cattle by using a high frequency linear-array transducer.

\begin{tabular}{|c|c|c|c|c|c|c|}
\hline $\begin{array}{l}\text { Days } \\
\text { after AI }\end{array}$ & $\mathbf{N}$ & $\begin{array}{l}\text { Sensitivity } \\
(\%)\end{array}$ & $\begin{array}{c}\text { Specificity } \\
(\%)\end{array}$ & $\begin{array}{c}\text { Positive } \\
\text { Predictive Value } \\
(\%)\end{array}$ & $\begin{array}{c}\text { Negative } \\
\text { Predictive Value } \\
(\%)\end{array}$ & References \\
\hline 27 & 1673 & 96.5 & 93.4 & 89.7 & 97.8 & $\begin{array}{c}\text { Silva et al. [18] } \\
\text { (5-10 MHz transducer) }\end{array}$ \\
\hline 28 & 100 & 92.7 & 91.5 & 88.4 & 94.7 & $\begin{array}{c}\text { Karen et al. [32] } \\
\text { (6-10 MHz transducer) }\end{array}$ \\
\hline \multirow{2}{*}{$28-35$} & \multirow{2}{*}{497} & $96^{a}$ & 83 & 91 & 92 & \multirow{2}{*}{$\begin{array}{c}\text { Nation et al. [16] } \\
\text { (7.5 MHz transducer) }\end{array}$} \\
\hline & & $97^{b}$ & 86 & 92 & 93 & \\
\hline $29-30$ & 138 & $90.4^{\mathrm{c}}$ & 96.0 & 95.0 & 92.3 & \multirow{3}{*}{$\begin{array}{c}\text { Szenci et al. [31] } \\
\text { (7.5 MHz transducer) }\end{array}$} \\
\hline $33-34$ & 135 & $96.6^{c}$ & 98.6 & 98.3 & 97.3 & \\
\hline $33-34$ & 135 & $90.0^{d}$ & 100 & 100 & 92.5 & \\
\hline 30 & 47 & 92.3 & 97.1 & 92.9 & 97.1 & $\begin{array}{l}\text { Abdullach et al. [33] } \\
\text { (6.5 MHz transducer) }\end{array}$ \\
\hline
\end{tabular}

${ }^{a}$ Observation of $\geq 15 \mathrm{~mm}$ fluid in the uterine lumen and embryonic membranes; ${ }^{b}$ Observation of an embryo with beating heart;

${ }^{c}$ Recognition of allantoic fluid was used as the criterion for a positive pregnancy diagnosis; ${ }^{\mathrm{d}}$ Recognition of an embryo proper with a beating heart was used as the criterion for a positive pregnancy diagnosis.

The reliability of the test greatly depends on the frequency of the transducer used, the skill of the operator $[30,34]$, the criterion used for a positive pregnancy diagnosis (uterine fluid or embryo [15,27,32]; uterine fluid, embryonic membranes, or embryo [16]; amniotic fluid and/or embryo surrounded by an amniotic sac [29]; normal amount of chorioallantoic fluid, embryo, ipsilateral CL [18]; embryo with a heartbeat and corpus luteum [35]; embryo with a heartbeat, fluid-filled uterine horn, ipsilateral corpus luteum [36,37]; amniotic fluid, embryo, or embryonic heartbeat [38]; accumulation of intrauterine gestural fluid in non-pregnant cows [25], and the position of the uterus in the pelvic inlet [39]. More incorrect non-pregnancy diagnoses were made between Days 24 to 38 in cows in which the uterus was located far cranial to the pelvic inlet, in comparison with cows in which the uterus was located within or close to the pelvic inlet [39]. It is important to mention if our ultrasonographic pregnancy diagnoses are based on detection of uterine fluid in the uterus on Day 29 after timed AI, at that time, these cows can be classified 3.8 times more likely as not pregnant 74 days after timed AI than those cows diagnosed pregnant based on visualization of an embryo with a heartbeat [36].

Special attention must be paid to the diagnosis of twin pregnancy by clearly locating the two embryos because twin pregnancy loss and spontaneous twin reduction have been reported to occur up to Day 90 of gestation [40,41]. Possibilities for diagnosing twin pregnancy in the field have been reviewed recently by Szelényi et al. [42].

\subsection{Color Flow Doppler Ultrasonography}

Color flow Doppler ultrasonography (CFDU) can be used to monitor blood flow in the corpus luteum (CL) around Day 20 after AI because luteal vascularization plays a decisive role in the functional evaluation of the corpus luteum [43-46]. On the other hand, there is a good correlation between decreasing blood flow during CL regression and progesterone concentration $[47,48]$. One of the main advantages of CFDU is its high sensitivity $(99 \%)$ and negative predictive value (98.5\%) of diagnosing non-pregnant dairy cattle on Day 20 after AI, which results in few false negative diagnoses [49]. According to Dubuc et al. [50], by monitoring the blood flow in the CL on Day 21 after $\mathrm{AI}$ in contrast with measuring the progesterone concentration, non-pregnancy in dairy cows on Day 32 after AI can also be predicted with high accuracy (sensitivity: $99.8 \%$, negative predictive value: $99.3 \%$ ). In a recent study, Siqueira et al. [51] have found that the reduction of blood flow in the CL takes place some days before any detectable changes in CL morphology and echotexture, and therefore, determination of the blood flow and the adjusted blood flow calculated from the 
ratio of luteal tissue area and blood flow were the best early predictors of non-pregnancy. In contrast, luteal tissue area and echotexture were found to be inconsistent early indicators of luteolysis.

\subsection{Conceptus Proteins}

Trophoblastic mono- and binucleate cells from the early bovine conceptus synthesize substantial amounts of proteins. Among these, one has been described as bovine pregnancy-specific protein B (bPSPB), which enters into the maternal circulation [52]. In addition, a bPSPB-related protein, designated bovine pregnancy-associated glycoprotein (bPAG; [53]) or bPAG-1 [54], as well as pregnancy serum protein $60 \mathrm{kDa}$ (PSP60; [55]) have been described. Pregnancy proteins are inactive members of the aspartic proteinase family (pepsins, cathepsins, and renins also belong to this family), and are identical in genetic nucleotide sequence [56-58]. The isolated preparations of pregnancy proteins may differ in carbohydrate and sialic acid content, which may explain their minor differences in profile and disappearance from the maternal circulation after calving or EM $[32,59,60]$. Because the concentrations of these proteins gradually increase during pregnancy, they are good indicators of the presence of a live embryo [61]. The pregnancy proteins have been detected in the serum of some pregnant cows as early as Days 15 to $22[61,62]$ or Day $22[55,63]$ after AI. Due to the delayed appearance of these proteins in the blood in some cows, their use for PD provides more accurate results from Days 28 to 30 onwards [32,57,64]. Both bPSPB and bPAG-1 have been detected in the peripheral circulation during the postpartum period 70 to 100 days after calving [61,65]. Likewise, Mialon et al. [55] reported similar residual protein concentrations for PSP60 after calving in the Charolais (mean: 107 days/91-119/), Normande (mean: 84 days/56-105/), and Holstein (mean: 88 days/63-126/) breeds. In a recent study, $56.7 \%$ and $44.9 \%$ of the false positive diagnoses based on bPSPB and bPAG-1 tests, respectively, originated from cows that were inseminated within 70 days after calving [32]. These findings indicate that the presence of bPSPB and bPAG-1 in the plasma of cows during the early stages of the postpartum period may limit their use under field conditions. If only those cows are selected for the protein tests, which are inseminated after Day 50 [66] or Day 70 after calving [67-69], post-calving interference with the residual bPSPB or bPAG-1 in the peripheral circulation during the postpartum period can be minimal.

A further limitation after late embryonic mortality (LEM) is that protein levels may remain above the threshold level, although the concentration of both proteins decreases steadily $[70,71]$. This is probably related to the relatively long half-life (7-8 days for bPSPB and 3-4 days for bPAG-1) in the maternal circulation after EM [70,72].

Serrano et al. [73] reported that the herd, fetal sex, milk production, lactation number, and plasma progesterone concentrations did not significantly influence the plasma PAG-1 concentration, while twin pregnancy, the use of Limousin semen and conception during the cool period significantly increased its concentrations throughout gestation. Clone pregnancies comparing with control cows may also significantly increase pregnancy protein concentrations during the whole gestation, regardless of pregnancy outcome [74].

\subsubsection{In-House PAGs ELISA Tests}

Originally PSPB, PAG-1, and PSP60 radioimmunoassay tests were used to detect pregnancy proteins; however, in the meantime, it turned out that there are 21 PAG family members, and PAG-1 used for pregnancy diagnosis was not the earliest pregnancy protein produced by the trophoblast [75]. After recognizing this, the first in-house sandwich ELISA protocol was developed for measuring the circulating concentration of PAGs by Green et al. [76] and Friedrich and Holtz [77]. Between Days 26 and 58 after AI, the sensitivity, specificity, positive predictive value, and negative predictive value of the inhouse PAGs ELISA tests varied between $94 \%$ and $100 \%, 77 \%$ and $94.2 \%, 90.7 \%$ and $97.8 \%$, and $91.2 \%$ and $97.1 \%$, respectively (Table 4 ). 
Table 4. Accuracy of in-house early-pregnancy associated glycoproteins (PAGs) ELISA tests for diagnosing early pregnancy in dairy cattle.

\begin{tabular}{|c|c|c|c|c|c|c|c|}
\hline $\begin{array}{c}\text { Days } \\
\text { after AI }\end{array}$ & $\mathbf{N}$ & $\begin{array}{l}\text { Type of } \\
\text { Sample }\end{array}$ & $\begin{array}{c}\text { Sensitivity } \\
(\%)\end{array}$ & $\underset{(\%)}{\text { Specificity }}$ & $\begin{array}{c}\text { Positive } \\
\text { Predictive Value } \\
(\%)\end{array}$ & $\begin{array}{c}\text { Negative } \\
\text { Predictive Value } \\
(\%)\end{array}$ & References \\
\hline $26-58$ & 169 & Serum & 97.8 & 91.2 & 97.8 & 91.2 & Piechotta et al. [78] ${ }^{a}$ \\
\hline $27-35$ & 2129 & \multirow{2}{*}{ Plasma } & 95.1 & 89.0 & 90.1 & 94.5 & \multirow{2}{*}{ Sinedino et al. [79] ${ }^{\mathrm{b}}$} \\
\hline $31-35$ & 209 & & 98.7 & 88.1 & 83.7 & 99.1 & \\
\hline $26-30$ & 106 & \multirow{4}{*}{ Serum * } & 94 & 77 & NG & NG & \multirow{4}{*}{$\begin{array}{l}\text { Friedrich and Holtz } \\
\text { [77] }\end{array}$} \\
\hline $31-35$ & 88 & & 95 & 93 & NG & NG & \\
\hline $36-40$ & 57 & & 95 & 93 & NG & NG & \\
\hline$>40$ & 128 & & 100 & 92 & NG & NG & \\
\hline 27 & 1673 & Plasma & 95.4 & 94.2 & 90.7 & 97.1 & Silva et al. [18] ${ }^{\mathrm{b}}$ \\
\hline 28 & 100 & Plasma & 95.3 & 88.3 & NG & NG & \multirow{2}{*}{$\begin{array}{c}\text { Thompson et al. } \\
{[80]^{\mathrm{b}}}\end{array}$} \\
\hline 30 & 100 & Plasma & 100 & 90.9 & NG & NG & \\
\hline
\end{tabular}

* using a threshold of $2 \mathrm{ng} / \mathrm{mL} ;{ }^{a}$ Used an in-house ELISA assay described by Friedrich and Holtz [77]; ${ }^{\mathrm{b}}$ Used an in-house ELISA assay described by Green et al. [76] (2005); NG: not given.

Mercadante et al. [81] found higher PAGs concentrations (in-house ELISA) in primiparous cows compared with multiparous pregnant cows (in agreement with Ricci et al. [36], while Kaya et al. [82] found similar differences between heifers and lactating cows), during the second and later breeding compared with the first breeding postpartum, in cows experiencing clinical metritis, metabolic problems and left displaced abomasum after calving compared with cows not experiencing those clinical diseases and in cases of greater milk yield, while the body condition score did not influence it. According to Dufour et al. [38], the accuracy of the PAG test (commercial milk ELISA) was not influenced by parity, the number of days, since the last breeding, and the level of milk production, while Ricci et al. [37] found a negative correlation between plasma and milk PAG concentration (commercial ELISA) and milk production.

\subsubsection{Commercial ELISA Tests}

There are currently several ELISA tests are available on the market, as discussed below.

BioPRYN ELISA test for the detection of pregnancy-specific protein B in the serum as early as 28 days after breeding in cattle with no interference from a previous pregnancy as early as 73 days after calving.

Between Days 26 to 58 after AI, the sensitivity, specificity, positive predictive value, and negative predictive value of the BioPRYN ELISA test varied between $93.9 \%$ and $100 \%$, $87 \%$ and $97.1 \%, 92 \%$ and $99.3 \%$, and $91.7 \%$ and $97.8 \%$, respectively (Table 5).

Martins et al. [83] compared the basal serum PSPB concentrations determined at Day 17 after AI with Day 23 results. They found that if the difference was more than $28 \%$ at that time the sensitivity, and the specificity of the ELISA test were higher (98\% and 97\%), compared to $92.8 \%$ and $97 \%$ obtained when only Day 23 values were evaluated. It is also important to mention that the concentrations of PSPB on Days 23 and 28 were related to pregnancy losses between Days 28 and 35 after AI, but not to those occurring in later periods (Days 35 to 56 and Days $>56$ to calving).

Middleton and Pursley [84] suggested comparing the results of serum PSPB samples withdrawn on Days 17 and 24 after AI to diagnose non-pregnant cows with 100\% accuracy at Day 24 after AI and to predict early pregnancy loss. 
Table 5. Accuracy of commercially available ByoPRYN pregnancy ELISA tests for diagnosing early pregnancy in dairy cattle.

\begin{tabular}{|c|c|c|c|c|c|c|c|}
\hline $\begin{array}{l}\text { Days } \\
\text { after AI }\end{array}$ & $\mathbf{N}$ & $\begin{array}{l}\text { Type of } \\
\text { Sample }\end{array}$ & $\begin{array}{c}\text { Sensitivity } \\
(\%)\end{array}$ & $\begin{array}{c}\text { Specificity } \\
(\%)\end{array}$ & $\begin{array}{c}\text { Positive } \\
\text { Predictive Value } \\
(\%)\end{array}$ & $\begin{array}{c}\text { Negative } \\
\text { Predictive Value } \\
(\%)\end{array}$ & References \\
\hline 23 & \multirow{3}{*}{544} & \multirow{3}{*}{ Serum } & 92.8 & 97.0 & \multirow{3}{*}{ NG } & \multirow{3}{*}{ NG } & \multirow{3}{*}{ Martins et al. [83] } \\
\hline $23^{a}$ & & & 98.0 & 97.0 & & & \\
\hline 28 & & & 100 & 91.6 & & & \\
\hline 24 & 206 & Serum & $100^{b}$ & $93.6^{\mathrm{b}}$ & $93.3^{b}$ & $100^{b}$ & $\begin{array}{c}\text { Middleton and } \\
\text { Pursley [84] }\end{array}$ \\
\hline $26-58$ & 185 & Serum & 98.0 & 97.1 & 99.3 & 91.7 & Piechotta et al. [78] \\
\hline 28 & 246 & \multirow{3}{*}{ Plasma } & 93.9 & 95.5 & 94.7 & 94.7 & \multirow{3}{*}{$\begin{array}{l}\text { Romano and } \\
\text { Larson [85] }\end{array}$} \\
\hline 30 & 229 & & 96.0 & 93.9 & 92.2 & 96.8 & \\
\hline 35 & 246 & & 97.2 & 93.6 & 92.0 & 97.8 & \\
\hline $28-41$ & 507 & \multirow{2}{*}{ Serum } & 97.0 & 95.9 & 96.2 & 96.7 & \multirow{2}{*}{ Breed et al. [86] } \\
\hline $35-60$ & 976 & & 96.6 & 92.2 & 95.0 & 94.7 & \\
\hline $30-36$ & 1742 & Serum & 95.1 & 68.6 & NG & NG & Gábor et al. [87] \\
\hline $30-36$ & 1336 & Serum & 100 & 87.8 & NG & NG & Howard et al. [88] \\
\hline
\end{tabular}

DG29 ${ }^{\circledR}$ Bovine Blood Pregnancy ELISA Test for the detection of specific pregnancyrelated protein in serum as early as 29 days after breeding in cattle with no interference from a previous pregnancy as early as 90 days after calving. Between Days 28 and 40, after AI the sensitivity, specificity, positive predictive value, and negative predictive value of the D29 test varied between $90.2 \%$ and $100 \%, 66.7 \%$ and $98.3 \%, 91 \%$ and $97.4 \%$, and $93.7 \%$ and $100 \%$, respectively (Table 6).

Table 6. Accuracy of commercially available D $29^{\circledR}$ bovine blood pregnancy ELISA tests for diagnosing early pregnancy in dairy cattle.

\begin{tabular}{cccccccc}
\hline $\begin{array}{c}\text { Days } \\
\text { after AI }\end{array}$ & $\mathbf{N}$ & $\begin{array}{c}\text { Type of } \\
\text { Sample }\end{array}$ & $\begin{array}{c}\text { Sensitivity } \\
\mathbf{( \% )}\end{array}$ & $\begin{array}{c}\text { Specificity } \\
\mathbf{( \% )}\end{array}$ & $\begin{array}{c}\text { Positive } \\
\text { Predictive Value } \\
\mathbf{( \% )}\end{array}$ & $\begin{array}{c}\text { Negative } \\
\text { Predictive Value } \\
\mathbf{( \% )}\end{array}$ & References \\
\hline 28 & 100 & serum & 90.2 & 98.3 & 97.4 & 93.7 & Karen et al. [31] \\
\hline $29-36$ & 202 & blood & 99.4 & $66.7 *$ & 92.6 & 96.3 & Paré et al. [89] \\
\hline $30-40$ & 212 & plasma & 100 & 81.3 & 91 & 100 & Moussafir et al. \\
[90]
\end{tabular}

${ }^{*} 100 \%$ in non-inseminated cows.

The IDEXX Bovine Pregnancy ELISA Test for the detection of early pregnancyassociated glycoproteins in the serum or plasma of cattle as early as 28 days after breeding in cows with no interference from a previous pregnancy as early as 60 days after calving. Between Days 25 and $\sim 41$, after AI the sensitivity, specificity, positive predictive value, and negative predictive value of the test varied between $92 \%$ and $100 \%, 87 \%$ and $100 \%, 84 \%$ and $100 \%$, and $94.2 \%$ and $100 \%$, respectively (Table 7 ).

The IDEXX Milk Pregnancy ELISA Test for the detection of pregnancy-associated glycoproteins in bovine milk from 28 days after breeding in cows with no interference from a previous pregnancy as early as 60 days after calving. Between Days 28 to $\sim 53$, after AI the sensitivity, specificity, positive predictive value, and negative predictive value of the test varied between $96 \%$ and $100 \%, 83 \%$ and $97.9 \%, 79 \%$ and $98.5 \%$, and $96 \%$ and $100 \%$, respectively (Table 8 ). While on Day $\geq 60$, the sensitivity and the specificity of the test varied between $98.5-99.2 \%$ and $95.5-96.7 \%$, respectively, the positive predictive value and the negative predictive value were $99.8 \%$ and $80.8 \%$, respectively (Table 8 ). It is important 
to mention that the plasma PAG levels turned out to be approximately twice higher than the milk PAG levels [36].

Table 7. Accuracy of commercially available IDEXX bovine pregnancy ELISA tests for diagnosing early pregnancy in dairy cattle.

\begin{tabular}{|c|c|c|c|c|c|c|c|}
\hline $\begin{array}{c}\text { Days } \\
\text { after AI }\end{array}$ & $\mathbf{N}$ & $\begin{array}{l}\text { Type of } \\
\text { Sample }\end{array}$ & $\begin{array}{c}\text { Sensitivity } \\
(\%)\end{array}$ & $\begin{array}{c}\text { Specificity } \\
(\%)\end{array}$ & $\begin{array}{c}\text { Positive } \\
\text { Predictive Value } \\
\text { (\%) }\end{array}$ & $\begin{array}{c}\text { Negative } \\
\text { Predictive Value } \\
(\%)\end{array}$ & References \\
\hline 25 & 61 & \multirow{4}{*}{ plasma } & 92.0 & 91.6 & 88.4 & 94.2 & \multirow{4}{*}{ Kaya et al. [82] } \\
\hline 28 & 84 & & 97.1 & 100 & 100 & 98.0 & \\
\hline 32 & 86 & & 97.4 & 91.4 & 90.4 & 97.7 & \\
\hline $25-32$ & 231 & & 95.9 & 94.7 & 93.1 & 96.9 & \\
\hline 28 & 210 & serum & 100 & 94.9 & 94.4 & 100 & Akkose et al. [91] \\
\hline 28 & 320 & plasma & $97 *$ & $94^{* *}$ & $95^{* *}$ & $97^{*}$ & Mayo et al. [92] \\
\hline $30 \pm 1$ & 116 & plasma & 100 & 88.9 & 93.8 & 100 & \multirow{2}{*}{ Commun et al. [93] } \\
\hline $30 \pm 1$ & 116 & serum & 100 & 88.6 & 93.8 & 100 & \\
\hline 32 & 141 & plasma & 100 & 87 & 84 & 100 & Ricci et al. [37] \\
\hline $41 \pm 2$ & 116 & plasma & 100 & 100 & 100 & 100 & \multirow{2}{*}{ Commun et al. [93] } \\
\hline $41 \pm 2$ & 116 & serum & 98.4 & 96.8 & 98.4 & 96.8 & \\
\hline
\end{tabular}

Table 8. Accuracy of commercially available milk pregnancy ELISA tests for diagnosing early pregnancy in dairy cattle.

\begin{tabular}{ccccccc}
\hline $\begin{array}{c}\text { Days } \\
\text { after AI }\end{array}$ & $\mathbf{N}$ & $\begin{array}{c}\text { Sensitivity } \\
\mathbf{( \% )}\end{array}$ & $\begin{array}{c}\text { Specificity } \\
\mathbf{( \% )}\end{array}$ & $\begin{array}{c}\text { Positive } \\
\text { Predictive Value } \\
\mathbf{( \% )}\end{array}$ & $\begin{array}{c}\text { Negative } \\
\text { Predictive Value } \\
\mathbf{( \% )}\end{array}$ & References \\
\hline 28 & 320 & $96^{*}$ & $94^{*}$ & $94 *$ & $9^{*}$ & Mayo et al. [92] \\
\hline $28-45$ & 497 & 99 & 95 & NG & Dufour et al. [38] \\
\hline $28-35$ & 1006 & 99.2 & 93.4 & NG & Fosgate et al. [34] \\
\hline $30 \pm 1$ & 116 & 98.1 & 90.3 & 94.5 & 96.6 & Commun et al. [92] \\
\hline 32 & 135 & 98 & 83 & 79 & 99 & Ricci et al. [37] \\
\hline $33-52$ & 119 & 100 & 97.9 & 98.5 & 100 & Lawson et al. [94] \\
\hline $41 \pm 2$ & 116 & 100 & 92.3 & 96.4 & 900 & Commun et al. [93] \\
\hline $53 \pm 2$ & 116 & 98.1 & 96.2 & 98.1 & 96.2 & LeBlanc [95] \\
\hline$\geq 60$ & 683 & 99.2 & 95.5 & 99.8 & NG & Byrem et al. [96] \\
\hline$\geq 60$ & 602 & 98.5 & 96.7 & NG &
\end{tabular}

NG: not given, ${ }^{*} \pm 2$.

The Rapid Visual Pregnancy ELISA test has been recently developed to detect early pregnancy-associated glycoproteins in bovine whole blood, plasma, or serum as early as 28 days after breeding with no interference from a previous pregnancy as early as 60 days after calving.

This test can be run without ELISA instrumentation and read visually [97]. Between Days 25 and 45 after AI, the sensitivity, specificity, positive predictive value, and negative predictive value of the visual blood test for dairy cattle were $99.8 \%, 91.7 \%, 92.7 \%$, and $99.7 \%$, respectively [97]. When the IDEXX visual ELISA test was used, the sensitivity, specificity, positive predictive value, and negative predictive value of the whole blood test were $98 \pm 1 \%, 85 \pm 3 \%, 87 \pm 3 \%$, and $98 \pm 1 \%$, respectively [92]. The high sensitivity and negative predictive values mean that very few truly pregnant cows were misdiagnosed as not pregnant. The overall accuracy of the test was $92 \pm 2 \%$ [92]. When a microtiter plate reader was used to measure the optical density for individual wells in the ELISA plate, the overall accuracy of the test became $94 \pm 1 \%$ [92]. According to the agreement analysis, 
a very good agreement between visual and milk ELISA tests (kappa: 0.92) and between visual and serum ELISA tests (kappa: 0.97), respectively, were reported [34].

The high overall accuracy of the test $(98.9 \%)$ was reported when the BioPRYN Rapid Visual Pregnancy Test ${ }^{\circledR}$ was used in 92 dairy cattle on Day 28 in heifers and on Day 30 in cows. However, it is important to mention that there were three samples evaluated as 'to be rechecked'; however, later, it was not possible to evaluate them, and therefore, these three samples were removed from the dataset [98]. A somewhat lower overall accuracy (90\%) was reported when the Ubio quickVET rapid visual test was used for plasma samples between Days 30 and 40 after AI [90], and a much lower accuracy (70\%) was obtained when the Fassisi ${ }^{\circledR}$ BoviPreg visual test kit was used for serum samples on Day 30 after AI [99].

\subsection{Early Pregnancy Factor (EPF)}

The earliest specific indicator of fertilization and the continuing presence of a viable conceptus is a serum constituent that had originally been detected in mice [100]. This substance is known as the early pregnancy factor (EPF) and has also been described in women [101], sheep [102], cattle [103], and pigs [104].

The reported and extraordinary properties of EPF include:

Early appearance (within hours) after mating or insemination

Rapid disappearance following induced death or removal of the embryos $[105,106]$.

These factors suggest that EPF may be the most useful tool for investigating early embryonic survival or failure [106-108]. According to Laleh et al. [109], the rosette inhibition test (RIT) has the potential to distinguish pregnant from non-pregnant dairy cows in the first week of pregnancy. However, the detection of EPF is entirely dependent on a bioassay that is not practical. After identifying immunosuppressive EPF with a molecular weight of approximately 200,000 and raising polyclonal antibodies against it [110], a new diagnostic test, the early conceptus factor (ECF) test, was developed in the USA for field use; however, it cannot accurately identify conception within days or at any time before Day 21 of gestation [111-115].

After EPF, a $10.84 \mathrm{kDa}$ protein, chaperonin 10 [116] having immunosuppressive and growth factor properties [117], was identified. Chaperonin 10 belongs to the family of heat shock proteins but, unlike other members of this family, EPF is detected extracellularly [117]. Further experimental work is needed for the development of an accurate on-farm diagnostic test.

\subsection{Current Developments in Early Pregnancy Diagnosis}

During elongation of the blastocyst, trophectoderm cells secret interferon-tau (IFNT) into the uterine cavity. With its very low levels in extrauterine tissues and in the peripheral circulation, IFNT is regarded as a signal for the maternal recognition of bovine pregnancy. INFT contributes to the maintenance of the CL by blocking prostaglandin $\mathrm{F}_{2 \alpha}$ secretion of the endometrium. Currently, there is no accurate assay for diagnosing early pregnancy based on measuring IFNT concentrations. At the same time, the determination of interferon-tau stimulated genes (ISG) has been recently suggested as an alternative method for the indirect detection of the conceptus itself. According to a recent review [14], the relative abundance of ISG in total leukocytes, peripheral blood mononuclear cells and polymorphonuclear cells in pregnant cows from Days 18 to 20 after AI may be significantly higher than in non-pregnant cows.

Another biomarker for diagnosing early pregnancy is the measurement of circulating microRNAs; however, their use is currently limited to research investigations because standardized laboratory techniques are needed to isolate and measure them [14].

Proteomics analysis of the milk identified three possible biomarkers (lactoferrin, lactotransferrin, and alpha1G) for diagnosing early pregnancy [118], while proteomics analysis of the blood identified another three genes (Myxovirus resistance: MX1 and MX2 and oligoadenylate synthetase-1: OAS1), which can be used for early pregnancy diagnosis after validation on a large number of dairy cows [119]. Glycans may also play some critical roles 
in both the normal function of cells and in disease; therefore, bovine pregnancy can be predicted from a glycan biomarker present in a cow's milk some 2-4 weeks earlier than by the standard method of pregnancy detection using ultrasonography [120]. Circulating nucleic acids (CNAs) or preimplantation factor (PIF) can be another biomarker for diagnosing early pregnancy in dairy cows [121,122], while Barbato et al. [123] suggested measuring PAG-2 mRNA in maternal blood cells, which can be detected earlier than the PAG-1 placental proteins in water buffalo and in other ruminants, as well.

These new branches of diagnostic sciences may contribute to finding molecules that may be exclusively related to maternal metabolic alterations during early embryonic development and to signaling for maternal recognition of pregnancy and continued survival [124], and may contribute to the development of an accurate early pregnancy diagnostic test in dairy cows.

A new technology (in-line milk analysis system, Herd Navigator) has already made possible the automatic collection of milk samples at milking robots or in the milking parlor to analyze progesterone, lactate dehydrogenase, and beta-hydroxybutyrate to detect estrus, tissue damage, and metabolic disorders, respectively [125]. According to Bruinjé and Ambrose [126], by using this new technology for early pregnancy diagnosis, a high sensitivity ( $>95 \%$ ) could be reached from Day 27 after AI, while the specificity was somewhat lower before Day 40 after AI. After finding an accurate biomarker for early pregnancy diagnosis, its continuous measurements during milking will make it possible to diagnose pregnancy loss much earlier, meaning we can greatly contribute to increasing reproductive efficiency in our dairy herds. The importance of this technology would also be emphasized by its ability to identify pregnant and non-pregnant animals in a timely manner with no animal handling, because even a simple transrectal examination of dairy cows can lead to increased plasma and salivary cortisol concentrations and changes in heart rate, heart rate variability, and behavior that are indicative of pain [127].

\section{Diagnosis of Pregnancy Losses (PL)}

\subsection{Ultrasonography}

One of the advantages of UEs is that PL can be recognized by the absence of a heartbeat, the detachment of the fetal membranes, the appearance of particles in the fetal fluids, or the lack of the embryo proper $[25,128]$. UEs have revealed that LEM may occur in up to $23 \%$ of pregnancies $[28,129]$. PL $(8 \%)$ diagnosed by ultrasonography in cows between Days 26 and 58 post-AI occurred at approximately Day $29(\mathrm{n}=1)$, Day $33(\mathrm{n}=3)$, Day $37(n=3)$, Day $40(n=2)$, Day $44(n=1)$, and Day $56(n=1)$ after AI. The exact day of occurrence of LEM/EFM could not be determined because UE was performed at intervals of 3-4 days [71].

According to Kelly et al. [130], decreased crown-rump length and progesterone concentration measured on Day 34 of gestation tended to be associated with an increased odds ratio for pregnancy loss, whereas CL perfusion and reduced blood flow of the uterine arteries evaluated by Doppler ultrasonography could not be used for predicting pregnancy loss in lactating dairy cattle.

\subsection{Pregnancy Proteins}

After diagnosing spontaneous cases of LEM by ultrasonography, both plasma bPSPB and bPAG-1 levels began to decline in most cases, while the CL continued to produce progesterone $[63,71,72]$. This confirms the previous observations $[70,131]$, and demonstrates that lower progesterone concentrations are not the cause of conceptus death.

Although the concentrations of both proteins decrease steadily $[70,71]$ after spontaneous or induced LEM/EFM, they reach the threshold level only after a relatively long half-life, namely, about 7 to 8 days for the bPSPB RIA test [70], and 3 to 4 days for the bPAG-1 RIA test [72]. Thus, they can contribute to the elevation of false positive pregnancy diagnoses on the farm. Similar results were reported by Giordano et al. [63] when inducing LEM on Day 39 of gestation and using the PSPB commercial and the PAG in-house ELISA 
tests. Although the threshold levels for these tests were not determined, they reached the basal levels in both tests approximately 5 to 7 days after inducing LEM. Based on commercial blood and milk ELISA tests, the threshold levels are reached approximately 7 to 14 days after pregnancy loss [37].

According to Mercadante et al. [81], reduced PAG concentrations (in-house ELISA) at Day 32 after AI may predict pregnancy loss between Days 46 and 74 of gestation. Based on positive and negative predictive value analysis, a circulating concentration of PAG (in-house ELISA) below $1.4 \mathrm{ng} / \mathrm{mL}$ in lactating dairy cattle following timed AI and $1.85 \mathrm{ng} / \mathrm{mL}$ following timed embryo transfer on Day 7 was 95\% accurate in predicting LEM/EFM (between Days 31 and 59) at Day 31 of gestation [13]. It has been recently reported that cows being pregnant at Day 31 of gestation and maintaining the pregnancy until Day 59 had significantly higher circulating concentrations of PAG (commercial ELISA test) at Day 31 of gestation compared with cows that experienced LEM/EFM between Days 31 and 59 of gestation [37]. In contrast, although there was a significant difference in the PAG concentrations measured on Day 24 after AI between pregnant and nonpregnant multiparous cows while in heifers only a tendency was detected at Day 31 after $\mathrm{AI}$, the circulating concentrations of PAG at Day 24 of gestation in animals that maintained pregnancy until Day 60 compared to animals that lost pregnancy between Days 31 and 60 of gestation, were not significantly different [132].

López-Gatius et al. [133] reported that low or very high plasma pregnancy-associated glycoprotein-1 (PAG-RIA) levels on Day 35 of gestation in cows were related to a subsequent pregnancy loss. Similarly, Gábor et al. [134] also found pregnancy losses in cows with high PSPB (commercial ELISA) concentrations $(>1.1 \mathrm{ng} / \mathrm{mL})$ and in cows with low concentrations of both PSPB and progesterone (0.6-1.1 and $<2 \mathrm{ng} / \mathrm{mL}$, respectively), however the prevalence of pregnancy loss was significantly lower in cows with high PSPB concentrations (15\%) between Days 29 and 35 of gestation than in those with low concentrations (76.3\%).

It has been recently reported that different PAG ELISA assays may accurately detect pregnancy; however, the ability to predict embryo survival vs. mortality during early gestation appears to be antibody-/assay-dependent [135].

In order to be able to decrease the effect of false positive diagnoses, due to pregnancy loss on the farm, it is necessary to repeat the pregnancy tests [136]. By using commercial plasma or milk ELISA tests, the optimal time for the first pregnancy diagnosis is around Day 32 after AI, when plasma and milk PAG levels are at an early peak. After this period, all pregnant cows should be retested on Day 74 after AI or later, when plasma and milk PAG levels rebound from their nadirs [37]. In contrast to the gradual increase in PAG-1 concentration (RIA) throughout gestation [61], plasma and milk PAG levels (commercial ELISA) reached a peak at Day 32 of gestation and then started to decrease to a nadir from Days 53 to 60 for the plasma PAG level and from Days 46 to 67 for the milk PAG level, followed by a gradual increase in PAG levels from Days 74 to 102 after AI [37].

The potential clinical significance of diagnosing pregnancy loss using ultrasonography or pregnancy protein tests and treating the cows with prostaglandin as soon as possible is that these measures may reduce the number of days before re-insemination [137].

\section{Future Perspectives}

Pregnancy diagnosis plays an essential role in decreasing days open in dairy farms; therefore, it is very important to select an accurate method for diagnosing early pregnancy, because the cost of each day open past 100 DIM may reach $\$ 4.00$ [138] or $€ 2.5$ to 6.5 [139], respectively. Besides traditional pregnancy diagnoses made by rectal palpation of the uterus from 40 to 60 days after AI and measuring the serum or milk progesterone concentration between 18 to 24 days after AI [14,140,141], there are several new possibilities to diagnose early pregnancy in dairy farms; however, it is very important to emphasize that before introducing any new diagnostic test we need to make sure the accuracy of that particular test to be able to decrease the rate of iatrogenic pregnancy losses caused by prostaglandin treatment to reduce the interval to the next AI service [140] or resynchro- 
nization of the cows [142,143]. Furthermore, the new pregnancy diagnostic results must be confirmed by the old diagnostic method to decrease the negative effects of false negative diagnoses [144]. Linear-array/sector B-mode [145] and Doppler ultrasonography [14] may exceed the other diagnostic methods in the amount of information collecting from each animal during scanning, however, their uses greatly depend on the operator proficiency and availability [145].

\section{Conclusions}

The successful genetic selection for higher milk production caused a dramatic decline in the reproductive performance of dairy cows all over the world during the last decades. Achievement of optimum herd reproductive performance (calving interval of 12 or 13 months with the first calf born at 24 months of age) requires concentrated management activities especially during calving and during the first 100 days following calving. One of the most important management activities needed to pursue during the early postpartum period to reach or approach the optimal reproductive performance is diagnosis of early pregnancy diagnosis and embryonic mortality in dairy cows. There are several diagnostic methods available for the dairy farms such as rectal palpation, transrectal ultrasonography, chemical and hormone assays, however, transrectal B-mode and Doppler ultrasonography may exceed the other diagnostic methods in the amount of information collecting from each animal during scanning in the farm. The advantages and disadvantages of the different diagnostic methods were discussed in order to be able to select the most accurate method for the dairy.

Funding: This research received no external funding.

Conflicts of Interest: The authors declare no conflict of interest.

\section{References}

1. Roche, J.F.; Boland, M.P.; McGeady, T.A. Reproductive wastage following artificial insemination in cattle. Vet. Rec. 1981, 109, 95-97. [CrossRef]

2. Saacke, R.G.; Dalton, C.; Nadir, S.; Nebel, R.L.; Bame, H. Relationship of seminal traits and insemination time to fertilization rate and embryo quality. Anim. Reprod. Sci. 2000, 60-61, 663-677. [CrossRef]

3. Butler, W.R. Review: Effect of protein nutrition on ovarian and uterine physiology in dairy cattle. J. Dairy Sci. 1998, 81, 2533-2539. [CrossRef]

4. López-Gatius, F. Is fertility declining in dairy cattle? A retrospective study in northeastern Spain. Theriogenology 2003, 60, 89-99. [CrossRef]

5. Galon, N. Factors affecting reproductive performance in Israeli dairy herds. In Factors Affecting Reproductive Performance in the Cow; Szenci, O., Bajcsy, Á.C., Eds.; Hungarian Association for Buiatrics: Budapest, Hungary, 2008; pp. 28-36.

6. Bouchard, E.; Du Tremblay, D. Dairy herd production and reproduction in Quebec and Canada. In Factors Affecting Reproductive Performance in the Cow; Szenci, O., Bajcsy, Á.C., Eds.; Hungarian Association for Buiatrics: Budapest, Hungary, 2008 ; pp. 60-66.

7. Nakao, T. Declining fertility in dairy cows in Japan and efforts to improve the fertility. In Factors Affecting Reproductive Performance in the Cow; Szenci, O., Bajcsy, Á.C., Eds.; Hungarian Association for Buiatrics: Budapest, Hungary, 2008; pp. $38-48$.

8. Wiltbank, M.C.; Baez, G.M.; Garcia-Guerra, A.; Toledo, M.Z.; Monteiro, P.L.; Melo, L.F.; Ochoa, J.C.; Santos, J.E.; Sartori, R. Pivotal periods for pregnancy loss during the first trimester of gestation in lactating dairy cows. Theriogenology 2016, 86, 239-253. [CrossRef] [PubMed]

9. Butler, W.R.; Smith, R.D. Interrelationships between energy balance on postpartum reproductive function in dairy cattle. J. Dairy Sci. 1989, 72, 767-783. [CrossRef]

10. Ujvári, V.; Niles, D.; Dinnyés, A.; Nagy, K.; Szenci, O. Retrospective evaluation of the results of embryo transfer, or insemination with sexed and traditional semen in heifers at an American Holstein-Friesian dairy farm. Magy. Állatorv. Lapja 2020, 142, 599-605.

11. Long, S. Abnormal development of the conceptus and its consequences. In Veterinary Reproduction and Obstetrics, 9th ed.; Noakes, D.E., Parkinson, T.J., England, G.C.W., Eds.; Saunders Elsevier: Edinburgh, UK, 2009; pp. 123-145.

12. López-Gatius, F.; Szenci, O.; Bech-Sàbat, G.; García-Ispierto, I.; Serrano, B.; Santolaria, P.; Yániz, J.L. Factors of non-infectious nature affecting late embryonic and early foetal loss in high producing dairy herds in north-eastern Spain. Literature review. Magy. Állatorv. Lapja 2009, 131, 515-531.

13. Pohler, K.G.; Pereira, M.H.C.; Lopes, F.R.; Lawrence, J.C.; Keisler, D.H.; Smith, M.F.; Vasconcelos, J.L.M.; Green, J.A. Circulating concentrations of bovine pregnancy-associated glycoproteins and late embryonic mortality in lactating dairy herds. J. Dairy Sci. 2016, 99, 1584-1594. [CrossRef] 
14. Pohler, K.G.; Reese, S.T.; Franco, G.A.; Oliveira Filho, R.V.; Paiva, R.; Fernandez, L.; Melo, G.; Vasconcelos, J.L.M.; Cooke, R.; Poole, R.K. New approaches to diagnose and target reproductive failure in cattle. Anim. Reprod. 2020, 17, e20200057. [CrossRef]

15. Pieterse, M.C.; Szenci, O.; Willemse, A.H.; Bajcsy, A.C.; Dieleman, S.J.; Taverne, M.A.M. Early pregnancy diagnosis in cattle by means of linear-array real-time ultrasound scanning of the uterus and a quantitative and qualitative milk progesterone test. Theriogenology 1990, 33, 697-707. [CrossRef]

16. Nation, D.P.; Malmo, J.; Davis, G.M.; Macmillan, K.L. Accuracy of bovine pregnancy detection using transrectal ultrasonography at 28 to 35 days after insemination. Aust. Vet. J. 2003, 81, 63-65. [CrossRef]

17. Romano, J.E.; Thompson, J.A.; Forrest, D.W.; Westhusin, M.E.; Tomaszweski, M.A.; Kraemer, D.C. Early pregnancy diagnosis by transrectal ultrasonography in dairy cattle. Theriogenology 2006, 66, 1034-1041. [CrossRef] [PubMed]

18. Silva, E.; Sterry, R.A.; Kolb, D.; Mathialagan, N.; McGrath, M.F.; Ballam, J.M.; Fricke, P.M. Accuracy of a pregnancy-associated glycoprotein (PAG) ELISA to determine pregnancy status of lactating dairy cows twenty-seven days after timed AI. J. Dairy Sci. 2007, 90, 4612-4622. [CrossRef] [PubMed]

19. Taverne, M.A.M.; Szenci, O.; Szétag, J.; Piros, A. Pregnancy diagnosis in cows with linear-array real-time ultrasound technique: A preliminary note. Vet. Q. 1985, 7, 264-270. [CrossRef] [PubMed]

20. Curran, S.; Pierson, R.A.; Ginther, O.J. Ultrasonographic appearance of the bovine conceptus from days 10 through 20. J. Am. Vet. Med. Assoc. 1986, 189, 1289-1294.

21. Curran, S.; Pierson, R.A.; Ginther, O.J. Ultrasonographic appearance of the bovine conceptus from days 20 through 60. J. Am. Vet. Med. Assoc. 1986, 189, 1295-1302. [PubMed]

22. Totey, S.M.; Singh, G.; Taneja, M.; Talwar, G.P. Ultrasonography for detection of early pregnancy following embryo transfer in unknown breed of Bos indicus cows. Theriogenology 1991, 35, 487-497. [CrossRef]

23. Boyd, J.S.; Omran, S.N.; Ayliffe, T.R. Use of a high frequency transducer with real time B-mode ultrasound scanning to identify early pregnancy in cows. Vet. Rec. 1988, 123, 8-11. [CrossRef]

24. Pierson, R.; Ginther, O. Ultrasonography for detection of pregnancy and study of embryonic development in heifers. Theriogenology 1984, 22, 225-233. [CrossRef]

25. Kastelic, J.P.; Bergfelt, D.R.; Ginther, O.J. Ultrasonic detection of the conceptus and characterisation of intrauterine fluid on days 10 to 22 in heifers. Theriogenology 1991, 35, 569-581. [CrossRef]

26. Filteau, V.; DesCoteaux, L. Valeur predictive de l'utilisation de l'appareil echographique pour le diagnostic precoce de la gestation chez la vache laitiere. Médecin Vétérinaire Québec 1998, 28, 81-85.

27. Szenci, O.; Piros, A.; Kovács, L. Early bovine pregnancy diagnosis by a battery operated portable ultrasonic scanner the Ultra-Scan In Proceedings of the 16th World Buiatrics Congress, Salvador, Brazil, 13-17 August 1990; pp. 219-223.

28. Hanzen, C.; Laurent, Y. Application de l'echographie bidimensionnelle au diagnostic de gestation et l'evaluation de l'incidence de la mortalit, embryonnaire dans l'espece bovine. Ann. Med. Vet. 1991, 134, 481-487.

29. Munoz del Real, L.M.; Valencia, G.L.; Corral, A.; Renteria, T. Evaluation of ultrasound for pregnancy diagnosis between 20 and 40 days post insemination in dairy cows. J. Anim. Vet. Adv. 2006, 5, 949-957.

30. Badtram, G.A.; Gaines, J.D.; Thomas, C.B.; Bosu, W.T.K. Factors influencing the accuracy of early pregnancy detection in cattle by real-time ultrasound scanning of the uterus. Theriogenology 1991, 35, 1153-1167. [CrossRef]

31. Szenci, O.; Beckers, J.F.; Humblot, P.; Sulon, J.; Sasser, G.; Taverne, M.A.M.; Varga, J.; Baltusen, R.; Schekk, G. Comparison of ultrasonography bovine pregnancy-specific protein $\mathrm{B}$, and bovine pregnancy-associated glycoprotein 1 tests for pregnancy detection in dairy cows. Theriogenology 1998, 50, 77-88. [CrossRef]

32. Karen, A.; De Sousa, N.M.; Beckers, J.F.; Bajcsy, Á.C.; Tibold, J.; Mádl, I.; Szenci, O. Comparison of a commercial bovine pregnancy-associated glycoprotein ELISA test and a pregnancy-associated glycoprotein radiomimmunoassay test for early pregnancy diagnosis in dairy cattle. Anim. Reprod. Sci. 2015, 159, 31-37. [CrossRef] [PubMed]

33. Abdullach, M.; Mohanty, T.K.; Kumaresan, A.; Mohanty, A.K.; Madkar, A.R.; Baithalu, R.K.; Bhakat, M. Early pregnancy diagnosis in dairy cattle: Economic importance and accuracy of ultrasonography. Adv. Anim. Vet. Sci. 2014, 2, 464-467. [CrossRef]

34. Fosgate, G.T.; Motimele, B.; Ganswindt, A.; Irons, P.C. Bayesian latent class model to estimate the accuracy of pregnancy diagnosis by transrectal ultrasonography and laboratory detection of pregnancy-associated glycoproteins in dairy cows. Prev. Vet. Med. 2017, 145, 100-109. [CrossRef]

35. Szenci, O.; Varga, J.; Bajcsy, A.C. Role of early pregnancy diagnosis be means of ultrasonography in improving reproductive efficiency in a dairy herd: A retrospective study. Bov. Pract. 1999, 33, 67-69.

36. Giordano, J.O.; Fricke, P.M. Accuracy of pregnancy diagnosis outcomes using transrectal ultrasonography 29 days after artificial insemination in lactating dairy cows. J. Dairy Sci. 2012, 95 (Suppl. 2), 75.

37. Ricci, A.; Carvalho, P.D.; Amundson, M.C.; Fourdraine, R.H.; Vincenti, L.; Fricke, P.M. Factors associated with pregnancyassociated glycoprotein (PAG) levels in plasma and milk of Holstein cows during early pregnancy and their effect on the accuracy of pregnancy diagnosis. J. Dairy Sci. 2015, 98, 2502-2514. [CrossRef] [PubMed]

38. Dufour, S.; Durocher, J.; Dubuc, J.; Dendukuri, N.; Hassan, S.; Buczinski, S. Bayesian estimation of sensitivity and specificity of a milk pregnancy-associated glycoprotein-based ELISA and of transrectal ultrasonographic exam for diagnosis of pregnancy at 28-45 days following breeding in dairy cows. Prev. Vet. Med. 2017, 140, 122-133. [CrossRef] [PubMed]

39. Szenci, O.; Gyulai, G.; Nagy, P.; Kovács, L.; Varga, J.; Taverne, M.A.M. Effect of uterus position relative to the pelvic inlet on the accuracy of early bovine pregnancy diagnosis by means of ultrasonography. Vet. Q. 1995, 17, 37-39. [CrossRef] [PubMed] 
40. López-Gatius, F.; Hunter, R.H.F. Spontaneous reduction of advanced twin embryos: Its occurrence and clinical relevance in dairy cattle. Theriogenology 2005, 63, 118-125. [CrossRef]

41. Szelényi, Z.; Szenci, O.; Répási, A.; de Sousa, M.N.; Beckers, J.F. Accuracy of diagnosing double corpora lutea and twin pregnancy by measuring serum progesterone and bovine pregnancy-associated glycoprotein 1 in the first trimester of gestation in dairy cows. Theriogenology 2015, 84, 76-81. [CrossRef]

42. Szelényi, Z.; Szenci, O.; Kovács, L.; García-Ispierto, I. Practical aspects of twin pregnancy diagnosis in cattle. Animals 2021, 11, 1061. [CrossRef]

43. Herzog, K.; Bollwein, H. Application of Doppler ultrasonography in cattle reproduction. Reprod. Domest. Anim. 2007, 42 (Suppl. 2), 51-58. [CrossRef]

44. Matsui, M.; Miyamoto, A. Evaluation of ovarian blood flow by colour Doppler ultrasound: Practical use for reproductive management in the cow. Vet. J. 2009, 181, 232-240. [CrossRef] [PubMed]

45. Lüttgenau, J.; Bollwein, H. Evaluation of bovine luteal blood flow by using color Doppler ultrasonography. Reprod. Biol. 2014, 14, 103-109. [CrossRef]

46. Bollwein, H.; Heppelmann, M.; Lüttgenau, J. Ultrasonographic Doppler use for female reproduction management. Vet. Clin. Food Anim. 2016, 32, 149-164. [CrossRef] [PubMed]

47. Herzog, K.; Brockhan-Ludemann, M.; Kasle, M.; Beindorff, N.; Paul, V.; Niemann, H.; Bollwein, H. Luteal blood flow is a more appropriate indicator for luteal function during the bovine estrous cycle than luteal size. Theriogenology 2010, 73, 691-697. [CrossRef] [PubMed]

48. Herzog, K.; Voss, C.; Kastelic, J.P.; Beindorff, N.; Paul, V.; Niemann, H.; Bollwein, H. Luteal blood flow increases during the first three weeks of pregnancy in lactating dairy cows. Theriogenology 2011, 75, 549-554. [CrossRef] [PubMed]

49. Siqueira, L.G.; Areas, V.S.; Ghetti, A.M.; Fonseca, J.F.; Palhao, M.P.; Fernandes, C.A.; Viana, J.H. Color Doppler flow imaging for the early detection of nonpregnant cattle at 20 days after timed artificial insemination. J. Dairy Sci. 2013, 96, 6461-6472. [CrossRef]

50. Dubuc, J.; Houle, J.; Rousseau, M.; Roy, J.-P.; Buczinski, S. Short communication: Accuracy of corpus luteum color flow Doppler ultrasonography to diagnose nonpregnancy in dairy cows on day 21 after insemination. J. Dairy Sci. 2020, 103, 2019-2023. [CrossRef]

51. Siqueira, L.G.; Arashiro, E.K.; Ghetti, A.M.; Souza, E.D.; Feres, L.F.; Pfeifer, L.F.; Fonseca, J.F.; Viana, J.H. Vascular and morphological features of the corpus luteum 12 to 20 days after timed artificial insemination in dairy cattle. J. Dairy Sci. 2019, 102, 5612-5622. [CrossRef] [PubMed]

52. Butler, J.E.; Hamilton, W.C.; Sasser, R.G.; Ruder, C.A.; Hass, G.M.; Williams, R.J. Detection and partial characterization of two bovine pregnancy-specific proteins. Biol. Reprod. 1982, 26, 925-933. [CrossRef]

53. Zoli, A.P.; Beckers, J.F.; Wouters-Ballman, P.; Closset, J.; Falmagne, P.; Ectors, F. Purification and characterization of a bovine pregnancy associated glycoprotein. Biol. Reprod. 1991, 45, 1-10. [CrossRef]

54. Xie, S.; Low, B.G.; Nagel, R.J.; Kramer, K.K.; Anthony, R.V.; Zoli, A.P.; Beckers, J.F.; Roberts, R.M. Identification of the major pregnancy-specific antigens of cattle and sheep as inactive members of the aspartic proteinase family. Proc. Natl. Acad. Sci. USA 1991, 88, 10247-10251. [CrossRef]

55. Mialon, M.M.; Camous, S.; Renand, G.; Martal, J.; Ménissier, F. Peripheral concentrations of a 60-kDa pregnancy serum protein during gestation and after calving and in relationship to embryonic mortality in cattle. Reprod. Nutr. Dev. 1993, 33, 269-282 [CrossRef]

56. Lynch, R.A.; Alexander, B.M.; Sasser, R.G. The cloning and expression of the bovine pregnancy-specific protein B (bPSPB) gene. Biol. Reprod. 1992, 46 (Suppl. 1), 72.

57. Vasquez, M.I.; Horta, A.E.M.; Marques, C.C.; Sasser, R.G.; Humblot, P. Levels of bPSPB throughout single and twin pregnancies after AI or transfer of IVM/IVF cattle embryos. Anim. Reprod. Sci. 1995, 38, 279-289. [CrossRef]

58. Xie, S.; Green, J.; Beckers, J.F.; Roberts, R.M. The gene encoding bovine pregnancy-associated glycoprotein-1, an inactive member of the aspartic proteinase family. Gene 1995, 159, 193-197. [CrossRef]

59. Beckers, J.F.; Zarrouk, A.; Batalha, E.S.; Garbayo, J.M.; Mester, L.; Szenci, O. Endocrinology of pregnancy: Chorionic somatomammotropins and pregnancy-associated glycoproteins: Review. Acta Vet. Hung. 1998, 46, 175-189.

60. Beckers, J.F.; Drion, P.V.; Garbayo, J.M.; Perényi, Z.; Zarrouk, A.; Sulon, J.; Remy, B.; Szenci, O. Pregnancy associated glycoproteins in ruminants: Inactive members of the aspartic proteinase family. Acta Vet. Hung. 1999, 47, 461-469.

61. Zoli, A.P.; Guilbault, L.A.; Delahaut, P.; Ortiz, W.B.; Beckers, J.F. Radioimmunoassay of a bovine pregnancy-associated glycoprotein in serum: Its application for pregnancy diagnosis. Biol. Reprod. 1992, 46, 83-92. [CrossRef]

62. Sasser, R.G.; Ruder, C.A.; Ivani, K.A.; Butler, J.E.; Hamilton, W.C. Detection of pregnancy by radioimmunoassay of a novel pregnancy-specific protein in serum of cows and a profile of serum concentrations during gestation. Biol. Reprod. 1986, 35, 936-942. [CrossRef] [PubMed]

63. Giordano, J.O.; Guenther, J.N.; Lopes, G.; Fricke, P.M. Changes in serum pregnancy-associated glycoprotein, pregnancy-specific protein B, and progesterone concentrations before and after induction of pregnancy loss in lactating dairy cows. J. Dairy Sci. 2012, 95, 683-697. [CrossRef]

64. Humblot, P.; Jeanguyot, N.; Ruder, C.A.; Leriche, I.; Thibier, M.; Sasser, R.G. Accuracy of pregnancy diagnosis by PSPB RIA in the plasma of dairy cows 28 days after AI. In Proceedings of the 11th International Congress on Animal Reproduction and Artificial Insemination, Dublin, Ireland, 26-30 June 1988; Volume 2, p. 3. 
65. Kirakofe, G.H.; Wright, J.M.; Schalles, R.R.; Ruder, C.A.; Paris, S.; Sasser, R.G. Pregnancy-specific protein B in serum of postpartum beef cows. J. Anim. Sci. 1993, 71, 2199-2205. [CrossRef]

66. Sasser, R.G.; Alexander, B.M.; Ruder, C.A. Pregnancy detection in postpartum cows by measurement of pregnancy specific protein B (PSPB). J. Anim. Sci. 1991, 69, 660.

67. Ruder, C.A.; Sasser, R.G. Source of bovine pregnancy-specific protein B (bPSPB) during the postpartum period and estimation of half-life of bPSPB. J. Anim. Sci. 1986, 63, 335.

68. Humblot, P.; Camous, S.; Martal, J.; Charlery, J.; Jeanguyot, N.; Thibier, M.; Sasser, R.G. Pregnancy specific protein B, progesterone concentrations and embryonic mortality during early pregnancy in dairy cows. J. Reprod. Fertil. 1988, 83, 215-223. [CrossRef]

69. Humblot, P.; Camous, S.; Martal, J.; Charlery, J.; Jeanguyot, N.; Thibier, M.; Sasser, R.G. Diagnosis of pregnancy by radioimmunoassay of a pregnancy-specific protein in the plasma of dairy cows. Theriogenology 1988, 30, 257-267. [CrossRef]

70. Semambo, D.K.N.; Eckersall, P.D.; Sasser, R.G.; Ayliffe, T.R. Pregnancy-specific protein B and progesterone in monitoring viability of the embryo in early pregnancy in the cow after experimental infection with Actinomyces pyogenes. Theriogenology 1992, 37, 741-748. [CrossRef]

71. Szenci, O.; Humblot, P.; Beckers, J.F.; Sasser, G.; Sulon, J.; Baltusen, R.; Varga, J.; Bajcsy, Á.C.; Taverne, M.A.M. Plasma profiles of progesterone and conceptus proteins in cows with spontaneous embryonic/foetal mortality as diagnosed by ultrasonography. Vet. J. 2000, 159, 287-290. [CrossRef]

72. Szenci, O.; Beckers, J.F.; Sulon, J.; Bevers, M.M.; Börzsönyi, L.; Fodor, L.; Kovács, F.; Taverne, M.A.M. Effect of induction of late embryonic mortality on plasma profiles of pregnancy associated glycoproteins in heifers. Vet. J. 2003, 165, 307-313. [CrossRef]

73. Serrano, B.; López-Gatius, F.; Santolaria, P.; Almería, S.; García-Ispierto, I.; Bech-Sabat, G.; Sulon, J.; de Sousa, N.M.; Beckers, J.F.; Yániz, J.L. Factors affecting plasma pregnancy-associated glycoprotein 1 concentrations throughout gestation in high-producing dairy cows. Reprod. Domest. Anim. 2009, 44, 600-605. [CrossRef]

74. Chavatte-Palmer, P.; de Sous, N.; Laigre, P.; Camous, S.; Ponter, A.A.; Beckers, J.F.; Heyman, Y. Ultrasound fetal measurements and pregnancy associated glycoprotein secretion in early pregnancy in cattle recipients carrying somatic clones. Theriogenology 2006, 66, 829-840. [CrossRef]

75. Green, J.A.; Xie, S.; Quan, X.; Bao, B.; Gan, X.; Mathialagan, N.; Beckers, J.F.; Roberts, R.M. Pregnancy-associated bovine and ovine glycoproteins exhibit spatially and temporally distinct expression patterns during pregnancy. Biol. Reprod. 2000, 62, 1624-1631. [CrossRef] [PubMed]

76. Green, J.A.; Parks, T.E.; Avalle, M.P.; Telugu, B.P.; McLain, A.L.; Peterson, A.J.; McMillan, W.; Mathialagan, N.; Hook, R.R.; Xie, S.; et al. The establishment of an ELISA for the detection of pregnancy-associated glycoproteins (PAGs) in the serum of pregnant cows and heifers. Theriogenology 2005, 63, 1481-1503. [CrossRef] [PubMed]

77. Friedrich, M.; Holtz, W. Establishment of an ELISA for measuring bovine pregnancy-associated glycoprotein in serum or milk and its application for early pregnancy detection. Reprod. Domest. Anim. 2010, 45, 142-146. [CrossRef] [PubMed]

78. Piechotta, M.; Bollwein, J.; Friedrich, M.; Heilkenbrinker, T.; Passavant, C.; Branen, J.; Sasser, G.; Hoedemaker, M.; Bollwein, H. Comparison of commercial ELISA blood tests for early pregnancy detection in dairy cows. J. Reprod. Dev. 2011, 57, 72-75. [CrossRef]

79. Sinedino, L.D.P.; Lima, F.S.; Bisinotto, R.S.; Cerri, R.L.A.; Santos, J.E.P. Effect of early or late resynchronization based on different methods of pregnancy diagnosis on reproductive performance of dairy cows. J. Dairy. Sci. 2014, 97, 4932-4941. [CrossRef]

80. Thompson, I.; Cerri, R.; Kim, I.; Green, J.; Santos, J.; Thatcher, W. Effects of resynchronization programs on pregnancy per artificial insemination, progesterone, and pregnancy-associated glycoproteins in plasma of lactating dairy cows. J. Dairy Sci. 2010, 93, 4006-4018. [CrossRef] [PubMed]

81. Mercadante, P.M.; Ribeiro, E.S.; Risco, C.; Ealy, A.D. Associations between pregnancy-associated glycoproteins and pregnancy outcomes, milk yield, parity, and clinical diseases in high-producing dairy cows. J. Dairy Sci. 2016, 99, 3031-3040. [CrossRef]

82. Kaya, M.S.; Köse, M.; Bozkaya, F.; Mutlu, H.; Uçar, E.H.; Atli, M.O. Early pregnancy diagnosis using a commercial ELISA test based on pregnancy-associated glycoproteins in Holstein-Friesian heifers and lactating cows. Turk. J. Vet. Anim. Sci. 2016, 40, 694-699. [CrossRef]

83. Martins, J.; Wang, D.; Mu, N.; Rossi, G.; Martini, A.; Martins, V.; Pursley, J. Level of circulating concentrations of progesterone during ovulatory follicle development affects timing of pregnancy loss in lactating dairy cows. J. Dairy Sci. 2018, 101, 10505-10525. [CrossRef]

84. Middleton, E.; Pursley, J. Blood samples before and after embryonic attachment accurately determine non-pregnant lactating dairy cows at $24 \mathrm{~d}$ post-artificial insemination using a commercially available assay for pregnancy-specific protein B. J. Dairy Sci. 2019, 102, 7570-7575. [CrossRef] [PubMed]

85. Romano, J.E.; Larson, J.E. Accuracy of pregnancy specific protein-B test for early pregnancy diagnosis in dairy cattle. Theriogenology 2010, 74, 932-939. [CrossRef]

86. Breed, M.W.; Guard, C.L.; White, M.E.; Smith, M.C.; Warnick, L.D. Comparison of pregnancy diagnosis in dairy cattle by use of a commercial ELISA and palpation per rectum. J. Am. Vet. Med. Assoc. 2009, 235, 292-298. [CrossRef]

87. Gábor, G.; Tóth, F.; Sasser, G.; Szász, F.; Bárány, I.; Wölfling, A.; Völgyi-Csík, J. Ways of decrease the period between calvings in dairy cows. Early pregnancy detection by Biopryn ELISA-test. Magy. Állatorv. Lapja 2004, 126, 459-464.

88. Howard, J.; Gábor, G.; Gray, T.; Passavant, C.; Ahmadzadeh, A.; Sasser, N.; Pals, D.; Sasser, G. BioPRYN, a blood-based pregnancy test for managing breeding and pregnancy in cattle. J. Anim. Sci. 2007, 58, 295-298. 
89. Paré, J.; Audet-Grenier, M.H.; Rouillier, P.; Sirard, M.A. Evaluation of the DG29 test for early detection of pregnancy in cattle. Can. Vet. J. 2008, 49, 1119-1121. [PubMed]

90. Moussafir, Z.; Allaia, L.; El Khalila, K.; Essamadib, A.; El Amiri, B. Could a bovine pregnancy rapid test be an alternative to a commercial pregnancy-associated glycoprotein ELISA test in dairy cattle? Anim. Reprod. Sci. 2018, 192, 78-83. [CrossRef]

91. Akkose, M.; Cebi-Sen, C.; Kirmit, A.; Korkmaz, O.; Yazlik, M.O.; Gocen, M.; Kuru, M.; Akçay, E. Pregnancy-associated glycoproteins (PAGs) and progesterone concentrations in Holstein heifers following two methods of estrus syncronization. Veterinaria México OA 2019, 2019, 646. [CrossRef]

92. Mayo, L.M.; Moore, S.G.; Poock, S.E.; Silvia, W.J.; Lucy, M.C. Technical note: Validation of a chemical pregnancy test in dairy cows that uses whole blood, shortened incubation times, and visual readout. J. Dairy Sci. 2016, 99, 7634-7641. [CrossRef]

93. Commun, L.; Velek, K.; Barbry, J.-B.; Pun, S.; Rice, A.; Mestek, A.; Egli, C.; Leterme, S. Detection of pregnancy-associated glycoproteins in milk and blood as a test for early pregnancy in dairy cows. J. Vet. Diagn. Investig. 2016, 28, 207-213. [CrossRef] [PubMed]

94. Lawson, B.C.; Shahzad, A.H.; Dolecheck, K.A.; Martel, E.L.; Velek, K.A.; Ray, D.L.; Lawrence, J.C.; Silvia, W.J. A pregnancy detection assay using milk samples: Evaluation and considerations. J. Dairy Sci. 2014, 97, 6316-6325. [CrossRef]

95. LeBlanc, S.J. Short communication: Field evaluation of a pregnancy confirmation test using milk samples in dairy cows. J. Dairy Sci. 2013, 96, 2345-2348. [CrossRef]

96. Byrem, T.M.; Velek, K.; Pearse, H.L. The Detection of Pregnancy Associated Glycoproteins (PAG) in Routine Milk Recording Samples as an Indicator of Pregnancy in Dairy Cattle. 2012. Available online: https://www.icar.org/wp-content/uploads/2015 /09/Byrem.pdf (accessed on 15 September 2015).

97. Green, J.C.; Volkmann, D.H.; Poock, S.E.; McGrath, M.F.; Ehrhardt, M.; Moseley, A.E.; Lucy, M.C. Technical note: A rapid enzyme-linked immunosorbent assay blood test for pregnancy in dairy and beef cattle. J. Dairy Sci. 2009, 92, 3819-3824. [CrossRef]

98. Hameed, O.A.; Mustafa, M.; Madi, N.; Tate, W. Evaluation of a rapid visual pregnancy (Bio-RPD) test for detection of pregnancy specific protein B (PSPB) in cow serum. J. Anim. Sci. Livest. Prod. 2020, 4, No.3:3.

99. Karakus, O.; Kadar, C.; Kuru, M.; Kaya, S.; Demir, M.C.; Arı, U.C.; Zonturlu, A.K.; Öztürkler, Y. Efficacy of a commercial test kit to determine early pregnancy in cows using whole blood and blood serum. Trop. Anim. Health Prod. 2021, 53, 28. [CrossRef]

100. Morton, H.; Hegh, V.; Clunie, G.J.A. Immunosuppression detected in pregnant mice by rosette inhibition. Nature 1974, 249, 459-460. [CrossRef] [PubMed]

101. Morton, H.; Rolfe, B.E.; Anderson, M.; Morrison, J. An early pregnancy factor detected in human serum by rosette inhibition test. Lancet 1977, 1, 394-397. [CrossRef]

102. Morton, H.; Clunie, G.J.A.; Shaw, F.D. A test for early pregnancy in sheep. Res. Vet. Sci. 1979, 26, 261-262. [CrossRef]

103. Nancarrow, C.D.; Wallace, A.L.L.; Grewal, A.S. The early pregnancy factor of sheep and cattle. J. Reprod. Fertil. 1981, 30, 191-197. [CrossRef]

104. Paisley, L.G.; Davis, W.C.; Anderson, P.B.; Mickelsen, W.D. Detection of early pregnancy factor in swine: A need for dialogue. Theriogenology 1982, 18, 393-401. [CrossRef]

105. Rolfe, B.; Cavanagh, A.; Forde, C.; Bastin, F.; Chen, C.; Morton, H. Modified rosette inhibition test with mouse lymphocytes for detection of early pregnancy factor in human pregnancy serum. J. Immunol. Methods 1984, 70, 1-11. [CrossRef]

106. Yamazaki, S.; Kawahata, K.; Goto, T.; Takahashi, J.; Yasuda, Y. EPF as a marker for early embryonic losses in repeat breeders. J. Reprod. Dev. 1995, 41, 129-132. [CrossRef]

107. Rolfe, B. Detection of foetal westage. Fertil. Steril. 1982, 37, 655-660. [CrossRef]

108. Koch, E. Early pregnancy factor: Its significance as an indicator of fertilization and embryonic mortality. In Embryonic Mortality in Farm Animals; Screenan, J.M., Diskin, M.G., Eds.; Martinus Nijhoff Publishers: Dordrecht, The Netherlands, 1986 ; pp. 74-92.

109. Laleh, V.G.; Laleh, R.G.; Pirany, N.; Ahrabi, M.M. Measurement of EPF for detection of cow pregnancy using rosette inhibition test. Theriogenology 2008, 70, 105-107. [CrossRef] [PubMed]

110. Threlfall, W.R. Immunosuppressive early pregnancy factor (ISEPF) determination for pregnancy diagnosis in dairy cows. Theriogenology 1994, 41, 317. [CrossRef]

111. Adams, C.S.; Jardon, P.W. Evaluation of the early conception factor tests in cows 3-7 days post-breeding. Proc. Am. Assoc. Bov. Pract. 1999, 32, 240-241. [CrossRef]

112. DesCoteaux, L.; Carrière, P.D.; Bigras-Poulin, M. Evaluation of the Early Conception Factor (ECF) dipstick test in dairy cows between days 11 and 15 post-breeding. Bov. Pract. 2000, 34, 87-91.

113. Cordoba, M.C.; Sartori, R.; Fricke, P.M. Assessment of a commercially available early conception factor (ECF) test for determining pregnancy status of dairy cattle. J. Dairy Sci. 2001, 84, 1884-1889. [CrossRef]

114. Gandy, B.; Tucker, W.; Ryan, P.; Williams, A.; Tucker, A.; Moore, A.; Godfrey, R.; Willard, S. Evaluation of the early conception factor $\left(\mathrm{ECF}^{\mathrm{TM}}\right)$ test for the detection of nonpregnancy in dairy cattle. Theriogenology 2001, 56, 637-647. [CrossRef]

115. Whisnant, C.S.; Pagels, L.A.; Daves, M.G. Case study: Effectiveness of a commercial early conception factor test for use in cattle. Prof. Anim. Sci. 2001, 17, 51-53. [CrossRef]

116. Cavanagh, A.C. Identification of early pregnancy factor as chaperonin 10: Implications for understanding its role. Rev. Reprod. 1996, 1, 28-32. [CrossRef]

117. Morton, H. Early pregnancy factor: An extracellular chaperonin 10 homologue. Immunol. Cell Biol. 1998, 76, 483-496. [CrossRef] 
118. Han, R.X.; Kim, H.R.; Diao, Y.F.; Lee, M.G.; il Jin, D. Detection of early pregnancy-specific proteins in Holstein milk. J. Proteom. 2012, 75, 3221-3229. [CrossRef] [PubMed]

119. Panda, B.S.K.; Mohapatrab, S.K.; Chaudharya, D.; Alhussienc, M.N.; Kapilab, R.; Danga, A.K. Proteomics and transcriptomics study reveals the utility of ISGs as novel molecules for early pregnancy diagnosis in dairy cows. J. Reprod. Immunol. 2020, 140, 103148. [CrossRef] [PubMed]

120. Taron, C.H.; Rudd, P.M. Glycomics: A Rapidly Evolving Field with a Sweet Future. Available online: https://www.researchgate. net/publication/311058088_Glycomics_a_rapidly_evolving_field_with_a_sweet_future/citations (accessed on 15 January 2016).

121. Mayer, J.; Soller, J.T.; Beck, J.; Purwins, V.; Wemheuer, W.; Schutz, E.; Brenig, B. Early pregnancy diagnosis in dairy cows using circulating nucleic acids. Theriogenology 2013, 79, 173-179. [CrossRef]

122. Ramu, S.; Stamatkin, C.; Timms, L.; Ruble, M.; Roussev, R.G.; Barnea, E.R. PreImplantation factor (PIF) detection in maternal circulation in early pregnancy correlates with live birth (bovine model). Reprod. Biol. Endocrin. 2013, 11, 105. [CrossRef] [PubMed]

123. Barbato, O.; Guelfi, G.; Barile, V.L.; Menchetti, L.; Tortiello, C.; Canali, C.; Brecchia, G.; Traina, G.; Beckers, J.F.; Sousa, N.M. Using real-time PCR to identify pregnancy-associated glycoprotein 2 (PAG-2) in water buffalo (Bubalus bubalis) blood in early pregnany. Theriogenology 2017, 89, 106-113. [CrossRef] [PubMed]

124. Balhara, A.K.; Gupta, M.; Singh, S.; Ashok, K.; Mohanty, A.K.; Singh, I. Early pregnancy diagnosis in bovines: Current status and future directions. Sci. World J. 2013. [CrossRef] [PubMed]

125. Saint-Dizier, M.; Chastant-Maillard, S. Potential of connected devices to optimize cattle reproduction. Theriogenology 2018, 112, 53-56. [CrossRef] [PubMed]

126. Bruinjé, T.C.; Ambrose, D.J. Technical note: Validation of an automated in-line milk progesterone analysis system to diagnose pregnancy in dairy cattle. J. Dairy Sci. 2019, 102, 3615-3621. [CrossRef]

127. Kovács, L.; Kézér, F.L.; Kulcsár-Huszenicza, M.; Ruff, F.; Szenci, O.; Jurkovich, V. Hypothalamic-pituitary-adrenal and cardiac autonomic responses to transrectal examination differ with behavioral reactivity in dairy cows. J. Dairy Sci. 2016, 99, 7444-7457. [CrossRef] [PubMed]

128. Semambo, D.K.N.; Boyd, J.S.; Taylor, D.J.; Ayliffe, T.R.; Omran, S.N. Ultrasonographic study of early embryonic loss induced by Actinomyces pyogenes in cattle. Vet. Rec. 1992, 131, 7-12. [CrossRef]

129. Chaffaux, S.; Reddy, G.N.S.; Valon, F.; Thibier, M. Transrectal real-time ultrasound scanning for diagnosing pregnancy and for monitoring embryonic mortality in dairy cattle. Anim. Reprod. Sci. 1986, 10, 193-200. [CrossRef]

130. Kelly, D.E.; Galvao, K.N.; Mortensen, C.J.; Risco, C.A.; Ealy, A.D. Using Doppler ultrasonography on day 34 of pregnancy to predict pregnancy loss in lactating dairy cattle. J. Dairy Sci. 2017, 100, 3266-3271. [CrossRef]

131. Kastelic, J.P.; Northey, D.L.; Ginther, O.J. Spontaneous embryonic death on days 20 to 40 in heifers. Theriogenology 1991, 35, 361-363. [CrossRef]

132. Reese, S.T.; Pereira, M.H.C.; Edwards, J.L.; Vasconcelos, J.L.M.; Pohler, K.G. Pregnancy diagnosis in cattle using pregnancy associated glycoprotein concentration in circulation at day 24 of gestation. Theriogenology 2018, 106, 178-185. [CrossRef]

133. López-Gatius, F.; Hunter, R.H.; Garbayo, J.M.; Santolaria, P.; Yaniz, J.; Serrano, B.; Ayad, A.; De Sousa, N.M.; Beckers, J.F. Plasma concentrations of pregnancy-associated glycoprotein-1 (PAG-1) in high producing dairy cows suffering early fetal loss during the warm season. Theriogenology 2007, 67, 1324-1330. [CrossRef] [PubMed]

134. Gábor, G.; Kastelic, J.P.; Abonyi-Tóth, Z.; Gábor, P.; Endrődi, T.; Balogh, O.G. Pregnancy loss in dairy cattle: Relationship of ultrasound, blood pregnancy-specific protein B, progesterone and production variables. Reprod. Domest. Anim. 2016, 51, 467-473. [CrossRef]

135. Gatea, A.O.; Smith, M.F.; Pohler, K.G.; Egen, T.; Pereira, M.H.C.; Vasconselos, J.L.M.; Lawrence, J.C.; Green, J.A. The ability to predict pregnancy loss in cattle with ELISAs that detect pregnancy associated glycoproteins is antibody dependent. Theriogenology 2018, 108, 269-276. [CrossRef] [PubMed]

136. López-Gatius, F.; García-Ispierto, I. Ultrasound and endocrine findings that help to assess the risk of late embryo/early foetal loss by non-infectious cause in dairy cattle. Reprod. Domest. Anim. 2010, 45 (Suppl. 3), 15-24. [CrossRef]

137. Baxter, S.J.; Ward, W.R. Incidence of fetal loss in dairy cattle after pregnancy diagnosis using an ultrasound scanner. Vet. Rec. 1997, 140, 287-288. [CrossRef] [PubMed]

138. Des Coteaux, L.; Fetrow, J. Does it pay to use an ultrasound machine for early pregnancy diagnosis in dairy cows? In Proceedings of the 31st AABP Annual Meeting, Spokane, WA, USA, 24-27 September 1998; pp. 172-174.

139. Fodor, I.; Ózsvári, L. Early pregnancy diagnosis on large dairy farms and its role in improving profitability: Literature review. AWETH 2018, 14, 22-36.

140. Fricke, P.M.; Ricci, A.; Giordano, J.O.; Carvalho, P.D. Methods for and implementation of pregnancy diagnosis in dairy cows. Vet. Clin. Food. Anim. 2016, 32, 165-180. [CrossRef]

141. Reese, S.T.; Pereira, M.C.; Vasconcelos, J.L.M.; Smith, M.F.; Green, J.A.; Geary, T.W.; Peres, R.F.G.; Perry, G.A.; Pohler, K.G. Markers of pregnancy: How early can we detect pregnancies in cattle using pregnancy-associated glycoproteins (PAGs) and microRNAs? Anim. Reprod. 2016, 13, 200-208. [CrossRef]

142. Silva, E.; Sterry, R.A.; Kolb, D.; Mathialagan, N.; McGrath, M.F.; Ballam, J.M.; Fricke, P.M. Effect of interval to resynchronization of ovulation on fertility of lactating Holstein cows when using transrectal ultrasonography or a pregnancy-associated glycoptorein (PAG) ELISA to diagnose pregnancy status. J. Dairy Sci. 2009, 92, 3643-3650. [CrossRef] 
143. Green, J.C.; Newsom, E.M.; Lucy, M.C. Incorporation of a rapid pregnancy-associated glycoprotein ELISA into a CIDR-Ovsynch resynchronization program for a 28 day re-insemination interval. Theriogenology 2011, 75, 320-328. [CrossRef] [PubMed]

144. Szenci, O.; Taverne, M.A.M.; Beckers, J.F.; Sulon, J.; Varga, J.; Börzsönyi, L.; Hanzen, C.; Schekk, G. Evaluation of false ultrasonographic diagnoses in cows measuring plasma levels of bovine pregnancy associated glycoprotein (bPAG). Vet. Rec. 1998, 142, 304-306. [CrossRef] [PubMed]

145. Fricke, P.M. Scanning the future-Ultrasonography as a reproductive management tool for dairy cattle. J. Dairy Sci. 2002, 85, 1918-1926. [CrossRef] 